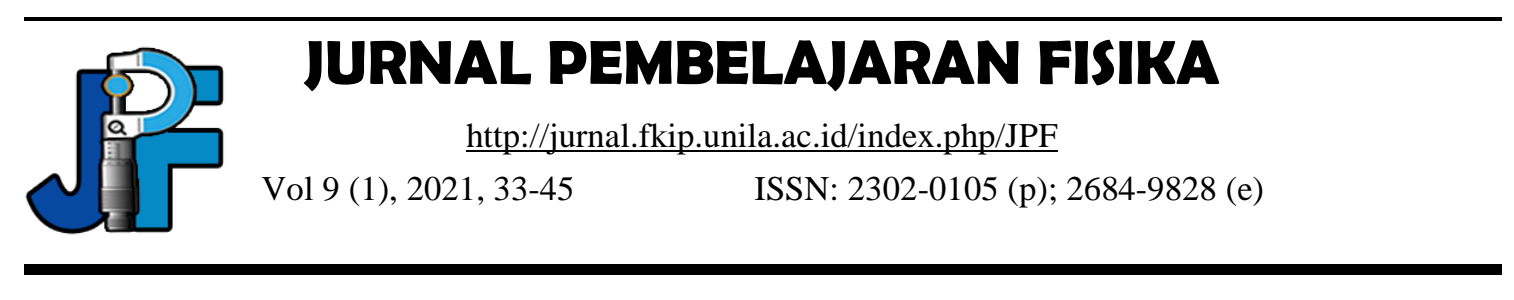

\title{
Development of Higher Order Thinking Skill (HOTS) Test Instruments based on Wondershare Quiz Creator
}

\author{
Devi Apriliana Amesa Putri M.*, Maryani Maryani, Pramudya Dwi Aristya Putra \\ Universitas Jember, Kalimantan Street No. 37, Kampus Tegalboto, Jember, Jawa Timur, 68121, \\ Indonesia \\ *e-mail: deviapriliana0@gmail.com
}

Received: Juni 10, 2021

Accepted: June 31, 2021

Published: July 19, 2021

\begin{abstract}
Critical thinking students can be improved by making questions in the test instrument categorized as Higher Order Thinking Skill (HOTS), because students are given HOTS category questions, it will train students in high-level problem-solving. This research develops a test instrument in the category of Higher Order Thinking Skill (HOTS) based on Wondershare Quiz Creator because it can train students to use the development of Science and Technology. The purpose of this development research to developing a test instrument based on Wondershare Quiz Creator to know the completeness of student learning outcomes and the critical thinking of students. This research used Research and Development (R \& D) type and the sample as many as 35 students of XII MIPA 4 in SMAN 1 Tanggul. This design research used Plomp and Nieveen's development style. Product testing is carried out online using the test instrument software that has been developed. The test instrument developed was declared valid and could be used in learning, from 35 students, there are 5 students who have completed their learning outcomes, and there are 2 students who have very high critical thinking skills.
\end{abstract}

Keywords: Completeness learning outcomes, Critical thinking skills, Higher Order Thinking Skill (HOTS), Test instrument

DOI: http://dx.doi.org/10.23960/jpf.v9.n1.202104 


\section{INTRODUCTION}

In the era of globalization, an important competency possessed by every individual is critical thinking, because in the current state is very easy to obtain information. Therefore, each individual must have critical thinking skill in order to be able to sort out positive information (Riskiyah, dkk, 2018). We can see the fact, in this globalization, many Indonesian students still have low critical thinking skills, based on the results of the Programne for International Student Assessment (PISA) in 2012, the literacy score of Indonesian students are 382 and on the rank $64^{\text {th }}$ out of 65 countries in the world. At that time a research was conducted by giving questions categorized as 6 cognitive levels, with level 1 being the lowest category and level 6 being the highest. Students in Indonesia can only answer at the cognitive level level 1 and level 2 only (Cholik, 2017).

The students who have low critical thinking skill can also be proven from their skill when answer every questions in the HOTS category, with categories of questions that require from analyzing, synthesizing, and evaluating which still not mastered by students (Mauludiyah, 2020). Technology, information and communication is currently developing very quickly. The developments that occur have an impact on all fields. Science and technology development, various fields use it to make work easier. One of the fields that utilize technology is education.

Educational backwardness that occurs in Indonesia still uses old patterns, such as students sitting in class and listening to the material delivered by the teacher. The process of learning can make students start to get bored and cause learning to be less than optimal, so the material captured by students is also less than optimal and not of high quality (Cholik, 2017). Field education develop a variety of technologies and instruments that are useful for improving the quality of learning, so that learning becomes effective and efficient. As teachers who are in this modern era, it is necessary to keep up current development so that students are more motivated and produce quality student.

To find out understanding every students about material being taught is by holding tests in order to get data on student learning outcomes. Tests are usually carried out at the beginning of learning and at the end of learning. At the beginning of learning, which is commonly referred to as (pre-test) is useful for measuring how far students understand the material to be taught, while post-test is useful for measuring how well students understand the material that has been taught. Test instruments can be used to measure student's problem solving abilities, but the test instruments developed or used must have validity and reliability (Sinesis, et al., 2019).

One of the uses of technology we often encounter in the world of education, namely the instrument used for tests to measure how far the knowledge of students after participating in learning activities. Not infrequently we encounter the test instrument used, namely using print media, but there are still many problems when using the test instrument in printed form. In addition to correcting the results of student's answers which take a long time, it also takes a long time to write answers to the essay questions.

Critical thinking students can be inproved by making questions in the test instrument categorized as Higher Order Thinking Skill (HOTS), because students are given questions in the HOTS category, it will train students in high-level problem 
solving, so that in the future they can be more accustomed to solving problems in the HOTS category. The test instrument that uses HOTS category questions is prepared based on indicators of high-level thinking with contextual questions and uses cognitive levels of analyze (C4), evaluate (C5), and create (C6), so that it can train and measure student's HOTS (Baidlowi, Hisham, Sunarmi, \& Sulisetijono, 2019).

Fanani (2018) argues that the characteristics of the HOTS assessment are that it can measure higher-order thinking skills, is based on contextual problems, is not familiar to students, and uses various forms of questions. Istiyono (2018) argues in his research that physics teacher's understanding of Higher Order Thinking Skills (HOTS) is still low, the application of HOTS assessments in physics is still low, and most physics teachers use power point, rarely use Computer Based Test (CBT) and almost never use Computer Assisted Test (CAT). So according to the researcher, further research is needed on the skills of physics teachers in preparing the HOTS assessment instrument and the development of CBT and CAT.

Test instruments can be made in the form of print media or in the form of software. Most teachers use print media as a test instrument. However, for print media, the teacher must correct the results of student answers manually, so it takes a lot of time to obtain student learning outcomes. With the development of technology, test instruments can be made using software, namely using Wondershare Quiz Creator. With this software, you can create questions of various types, ranging from multiple choice, descriptions, matchmaking, sorting, and filling in the blanks (Fazar, 2019). This software can also set the password of the test instrument, so that it can prevent questions from leaking before the test is carried out, besides that there is also a random question feature that can minimize the occurrence of cheating in the process. Making questions using this software can find out directly the scores received by students, so it's faster and there's no need to manually correct them (Fazar, 2019).

The theme of this research has also been researched by previous researchers who examined the HOTS test instrument development which provides an explanation of the effectiveness of using the instrument ineducation. Researchers Previously, including Wan Gunawan, et all who used Wondershare Quiz Creator software to create chemistry questions for class XI SMA, Eka in his research who developed a HOTS assessment instrument for high school students based on the 2013 curriculum, Sari, et al who developed a multiple choice test instrument on e-learning-based physics learning in high school, Faiqotul Himmah who developed a CBT-HOT test instrument for physics subjects in high school, Benidiktus Tanujaya who developed a Higher Order Thinking Skills test instrument for mathematics instruction based in high school, and Aniq Rif'atun, et al who developed a physics test instrument in the HOTS category in high school. All of their research resulted in a valid and effective test instrument used to measure student learning outcomes.

Wondershare Quiz Creator-based test instrument development is different from previous research. Previous research has been developed, but only on chemistry, besides that it also does not use HOTS category questions. There are also studies that use HOTS category questions, but do not use Wondershare Quiz Creator to create the test instrument. There is no test instrument based on Wondershare Quiz Creator that uses physics material and uses HOTS category questions. So that researchers are motivated to develop a HOTS test instrument based on Wondershare Quiz Creator on static 
electricity for class XII SMA. The advantage of developing test instruments using Wondershare Quiz Creator is that it can be accessed using any computer or laptop, either, can immediately know the results of each student's test, can be equipped with a password so that it is not easy to spread before the test is held, the questions entered consist of various kinds, ranging from true/false questions, multiple choice questions, response choices, descriptions, fill in the blanks, match, and sort. In addition, by using this software, you can enter the KKM so that you can immediately find out whether the student's learning outcomes are complete or not. This software is also equipped with a random question feature that can minimize student cheating. starting from true/false questions, multiple choice questions, response choices, descriptions, filling in the blanks, matching, and sorting. In addition, by using this software, you can enter the KKM so that you can immediately find out whether the student's learning outcomes are complete or not. This software is also equipped with a random question feature that can minimize student cheating. starting from true/false questions, multiple choice questions, response choices, descriptions, filling in the blanks, matching, and sorting. In addition, by using this software, you can enter the KKM so that you can immediately find out whether the student's learning outcomes are complete or not. This software is also equipped with a random question feature that can minimize student cheating.

The development of the HOTS test instrument was made to make it easier for educators to conduct tests and evaluate test results from students, because with the Wondershare Quiz Creator-based static electricity test instrument, they can directly provide an assessment of the evaluations carried out by participants. educate. This test instrument uses Wondershare Quiz Creator software in its manufacture and work on the questions to train students in the use of technology in education. This research aims to develop a software-based test instrument to train students in using the development of Science and Technology.

\section{METHOD}

\section{Type of Research}

The research type used is research and development (R \& D). This research used research design from Plomp and Nieveen. this research method, design, procedures are explained in the points below.

\section{Research Procedures}

The Plomp and Nieveen model is categorized as a development model that is more flexible and easier to compare, because at each step of the Plomp and Nieveen development model it contains activities from development that can be adapted to the characteristics of the research (Rochmad, 2012). Plomp \& Nieveen (2012) assembling a development model which consists of 3 stages including:

\section{a. Preliminary Research}

In this initial research stage, the process carried out is analyzing the needs and the existing context, revising the literature and developing concepts or theories used in research. The initial research stage carried out activities including analyzing the context 
and needs, namely analyzing the curriculum used, students, and teaching materials used. After that, a related theory study is carried out, then develops the theory to be tested.

\section{b. Prototyping Stage}

In the prototype stage, the design stage is repeated which becomes a research micro-cycle. The main activity at the prototype stage is formative evolution which is useful for improving and making a device. The prototype stage, a problem-solving design from the results of the analysis at the initial research stage has been compiled. Then the design of the learning device that will be developed begins to be designed. In addition, in the prototype stage, they also prepare or make research supporting instruments such as validity sheets, effectiveness sheets, and practicality sheets.

\section{c. Assessment Stage}

In the assessment stage, a summative evaluation is carried out which is useful for concluding that the device is in accordance with predetermined specifications or not, as well as to make suggestions from the development of the device that has been made. According to Plomp and Nieveen, this stage is carried out to evaluate the learning tools that have been developed, whether it meets or exceeds the criteria of the existing development. The assessment stage is also known as the semi-evaluation stage.

This research used Plomp and Nieveen development model, because this model has a clear and systematic procedure. The development model has been in accordance with the development model that the researcher will do. So the model for developing the HOTS test instrument based on Wondershare Quiz Creator uses the Plomp and Nieveen development models.

\section{Place and Time Research}

This research was carried out in SMAN 1 Tanggul when academic year 2020/2021 even semester, XII MIPA SMA in April 2021. The basis and mechanism of sampling in this research is by purposive sampling and quota sampling. The population used in this research were students of class XII MIPA 4 at SMAN 1 Tanggul and the research sample as many as 35 people.

\section{Data Collection and Instrument}

The following is an explanation of the data collection and instrument from the acquisition of the previously mentioned data are validity test data to obtain validation data from the Higher Order Thinking Skill (HOTS) test instrument based on Wondershare Quiz Creator to analyze the critical thinking skill of static electricity material for class XII SMA, the validator is given an assessment sheet and also a test instrument that has been developed by researchers to determine the level of validity. can add suggestions for revision if there are deficiencies. Validation tests in this study include validation of constructional study test instruments and technical studies. The second of data collection and instrument is used test. This test is an experimental test using an instrument that has been developed, namely using a test instrument based on the Wondershare Quiz Creator static electricity material. 


\section{Data Analysis}

a. Calculating Logical Validation Ratings from Validators

$$
V_{a}=\frac{\sum_{i=1}^{n} A_{i}}{n}
$$

$V a$ is the total average value of all aspects, $A i$ is the average value of the $\mathrm{i}$-th aspect and $n$ is the number of aspects.

After the $V a$ value is found, then the $V a$ value can we see in the table to determine the level of validity, in which the criteria for the level of validity are as follows.

Table 1. Validity Criteria

\begin{tabular}{cc}
\hline Category Validity & interval \\
\hline Invalid & $1 \leq \mathrm{V}_{\mathrm{a}}<2$ \\
Less Valid & $2 \leq \mathrm{Va}<3$ \\
Quite Valid & $3 \leq \mathrm{Va}<4$ \\
Valid & $4 \leq \mathrm{Va}<5$ \\
Very Valid & $=5$ \\
\hline
\end{tabular}

(Hobri, 2010)

The data from the validation calculations carried out by the validator, then analyzed descriptively in order to determine the validity of the HOTS test instrument for static electricity based on Wondershare Quiz Creator which will be used in class XII SMA.

\section{b. Completeness Analysis of Student Learning Outcomes}

The completeness of student learning outcomes when working on evaluation questions of learning outcomes when using the HOTS test instrument for static electricity based on Wondershare Quiz Creator is seen from the number of students who have scores above the KKM.

c. Analysis of Critical Thinking Skill

Researchers can analyze whether students meet the indicators of critical thinking skills in test instrument questions by using the equation:

$$
\text { Percentage value }=\frac{\text { Score obtained }}{\text { Maximum Score }}
$$

The percentage value of students' critical thinking skills can be included in the categories in Table 2 
Table 2. Criteria for Percentage of Critical Thinking Skill

\begin{tabular}{cc}
\hline Interpretation & Category \\
\hline $90 \% \times 100 \%$ & Very high \\
$75 \% \mathrm{x}<90 \%$ & High \\
$55 \% \mathrm{x}<75 \%$ & Medium \\
$40 \% \mathrm{x}<55 \%$ & Low \\
$0 \% \mathrm{x}<40 \%$ & Very low \\
\hline
\end{tabular}

(Karim, 2015)

\section{RESULT AND DISCUSSION}

\section{The research Description of Development Results}

This test instrument was developed with reference to the indicators on HOTS The initial display of this test instrument asks students to enter the password that has been given before the test. The password for this instrument has been given by the researcher, namely "static electricity" and can be changed at any time by the maker of this test instrument. After writing the password, a screen will appear to enter the email address and username of the teacher or instrument maker (adjusted for sending students' work results) (as shown in the attachment). After entering the email and username of the teacher or test instrument maker, a display appears to enter the student's identity.

This test instrument will display questions randomly and display options randomly, so that each student has a different view. Each question has a different processing time according to the systematic indicator of working on the problem. The processing time for each question is in the upper right corner, if students answer these questions beyond the specified time limit, they are automatically considered not to have answered the question. .

The developed Wondershare Quiz Creator-based test instrument can be run online or offline. The offline test instrument was developed in *.swf format and can be done either on a computer, laptop, or smartphone. Students who want to work on a computer or laptop, the student's computer or laptop must have Adobe Flash Player installed, but students who want to work on a smartphone can use additional applications that we can download on the Play Store. namely Webgenie SWF Player. This following are two examples result of the development of question with HOTS category in the test instrument based on Wondershare Quiz Creator. 


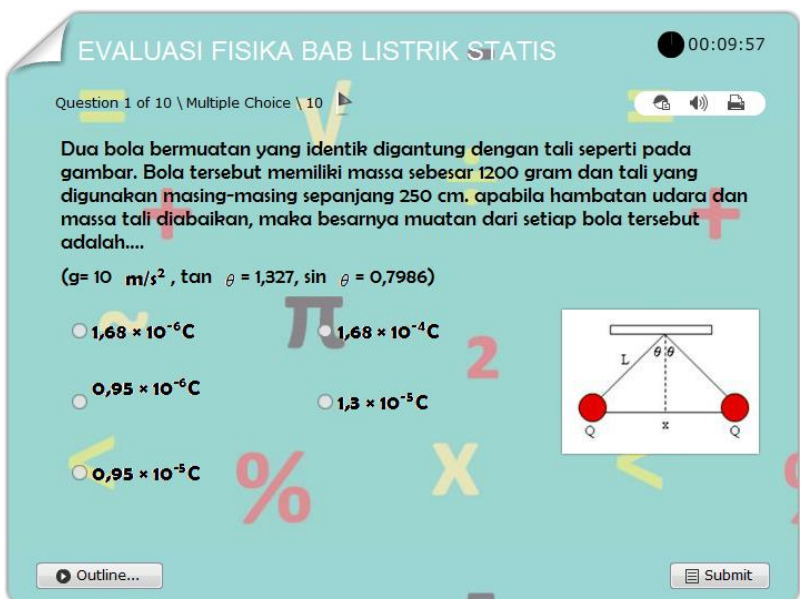

Picture 1. Question number one in test instrument

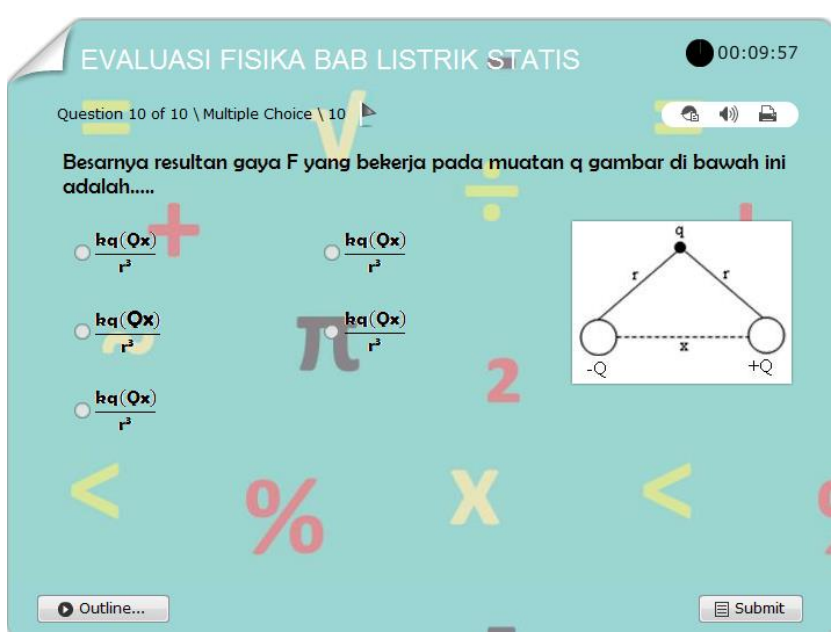

Picture 2. Question number two in test instrument

\section{Test Instrument Validation}

Validation includes validation of technical review test instruments and validation of constructional study test instruments. Validation of the technical study test instrument, the aspects assessed include format and language, while the validation of the constructional study test instrument, the aspects assessed include clarity, content accuracy, relevance, no bias, effectiveness, and feasibility of the test instrument. Validation of the test instrument was validated by 3 validators. The data of the test instrument validation are arranged in Table 3 and Table 4 below. 
Table 3. Quantitative Data of Test Instrument Validation Results

\begin{tabular}{|c|c|c|c|c|}
\hline No. & Aspect & $\begin{array}{c}\text { Average Validity o } \\
\text { Each Aspect }\end{array}$ & $\begin{array}{l}\text { Average } \\
\text { Validity }\end{array}$ & Category \\
\hline \multicolumn{5}{|c|}{ TECHNICAL VALIDITY } \\
\hline 1. & Format & 4.57 & \multirow{2}{*}{4.62} & \multirow{2}{*}{ Valid } \\
\hline 2. & Language & 4.67 & & \\
\hline \multicolumn{5}{|c|}{ CONSTRUCTIONAL VALIDITY } \\
\hline 1. & Clarity & 4.83 & \multirow{6}{*}{4.52} & \multirow{6}{*}{ Valid } \\
\hline 2. & Content accuracy & 4.67 & & \\
\hline 3. & Relevance & 4.41 & & \\
\hline 4. & No bias & 5 & & \\
\hline 5. & Effectiveness & 4.5 & & \\
\hline 6. & Appropriateness & 4.16 & & \\
\hline \multicolumn{5}{|c|}{ Table 4. Qualitative Data of Test Instrument Validation Results } \\
\hline Validator & \multicolumn{2}{|c|}{ General Rating } & \multicolumn{2}{|c|}{$\begin{array}{c}\text { General Comments and } \\
\text { Suggestions }\end{array}$} \\
\hline VA1 & \multicolumn{2}{|c|}{$\begin{array}{l}\text { Worth using for trial without } \\
\text { revision }\end{array}$} & \multicolumn{2}{|c|}{$\begin{array}{c}\text { In general it is good and can be } \\
\text { used }\end{array}$} \\
\hline VA2 & \multicolumn{2}{|c|}{$\begin{array}{l}\text { Worth using for trial without } \\
\text { revision }\end{array}$} & \multicolumn{2}{|c|}{$\begin{array}{l}\text { Instruments can be used in } \\
\text { research }\end{array}$} \\
\hline VP & \multicolumn{2}{|c|}{$\begin{array}{l}\text { Worth using for trial without } \\
\text { revision }\end{array}$} & \multicolumn{2}{|c|}{$\begin{array}{c}\text { The test instrument is suitable for } \\
\text { trial without revision }\end{array}$} \\
\hline
\end{tabular}

Based on the results of validation, the HOTS test instrument based on Wondershare Quiz Creator, the static electricity material developed, was declared valid and feasible to be used in trials and used in learning.

\section{Completeness of Student Evaluation Results}

The test instrument that has been developed is implemented for class XII students at SMAN 1 Tanggul. The curriculum used by SMAN 1 Tanggul is the 2013 Curriculum. The KKM for physics subjects at SMAN 1 Tanggul is 75. Students will be declared complete if the score is above the KKM. The completeness of the evaluation results of students using the HOTS test instrument based on Wondershare Quiz Creator are arranged in Table 5 below. 
Table 5. Completeness Data on Student Evaluation Results

\begin{tabular}{ccccc}
\hline Score & Frequency & KKM & Completeness & $\begin{array}{c}\text { Graduation } \\
\text { Frequency }\end{array}$ \\
\hline 10 & 5 & & Not pass & \\
20 & 1 & Not pass & \\
30 & 10 & Not pass & 30 \\
40 & 7 & Not pass & \\
50 & 3 & \multirow{2}{*}{75} & Not pass & \\
60 & 2 & & Not pass & \\
70 & 2 & Not pass & 5 \\
80 & 3 & Graduated & - \\
90 & 2 & Graduated & - \\
100 & 0 & & - & \\
\hline
\end{tabular}

Completeness of students can be seen in Table 5 above. Based on data that has been obtained, it is known that the number of students who get a value of 10 is 5 people, a value of 20 is 1 person, a value of 30 is 10 people, a value of 40 is 7 people, a value of 50 is 3 people, a value of 60 is 2 people, a score of 60 is 70 as many as 2 people, a score of 80 as many as 3 people, a score of 90 as many as 2 people, and no student who got a score of 100. Completeness of students can be seen in the table that students who did not pass were 30 people, while those who passed only only 5 people. This following are some of the scores obtained by students.

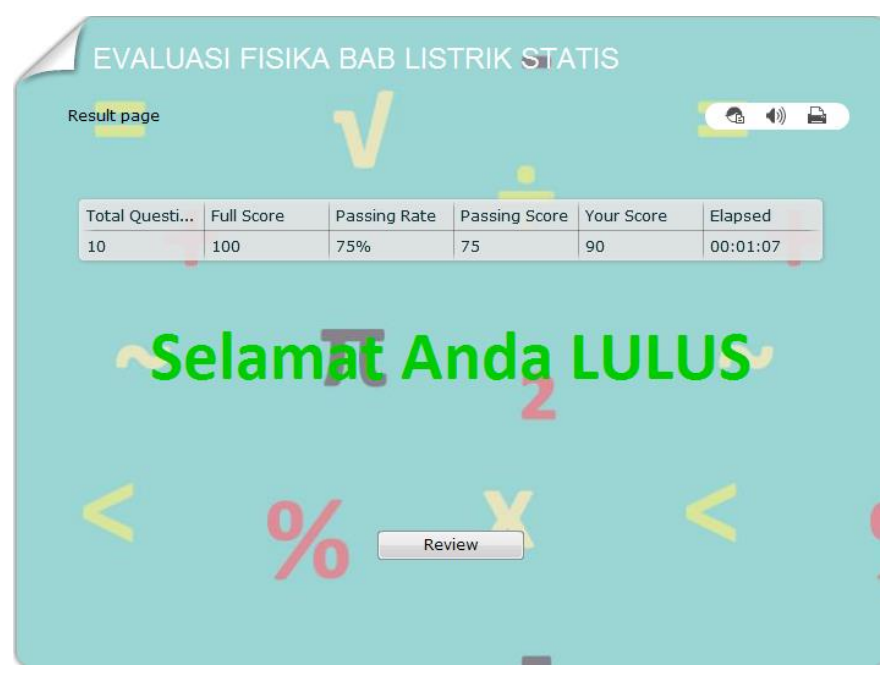

Picture 3. Student's score that completeness 


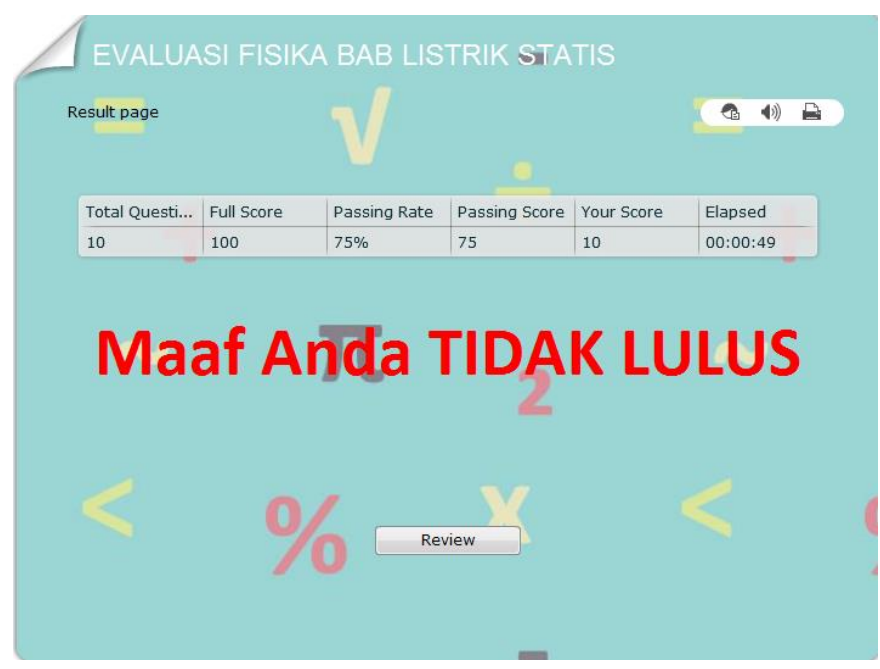

Picture 4. Student's score that not completeness

Whether or not students' learning outcomes are complete can be influenced by several factors. The learning outcomes of students really depend on the initial abilities possessed by students. In addition, there are several other factors that influence student learning outcomes including internal factors of students consisting of physiological conditions (physical conditions) of students and psychological factors (talents, interests, motivation, intelligence, cognitive abilities), while external factors of students students consist of environmental factors (social and natural) and instrument factors (facilities, infrastructure, teachers, curriculum, facilities provided) (Ardiawan, 2020).

\section{Critical Thinking Skill}

After getting data from the test of students using the HOTS instrument based on Wondershare Quiz Creator, the data was analyzed andresults of the analysis of student's critical thinking skills arranged in Table 6 below.

Table 6. Results of the Analysis of Students' Critical Thinking

\begin{tabular}{cccc}
\hline Interpretation & Frequency & $\begin{array}{c}\text { Percentage of } \\
\text { Number of Students } \\
(\%)\end{array}$ & Category \\
\hline $90 \% \times 100 \%$ & 2 & 5.71 & Very high \\
$75 \%$ x $<90 \%$ & 3 & 8.57 & High \\
$55 \%$ x $<75 \%$ & 4 & 11.43 & Medium \\
$40 \% \times<55 \%$ & 10 & 28.58 & Low \\
$0 \% \times<40 \%$ & 16 & 45.71 & Very low \\
\hline Number of Subjects & 35 & 100 & \\
\hline
\end{tabular}

The critical thinking skills presented in the table explained that the number of students who have critical thinking skills $90 \%$ x $100 \%$ there are 2 people who are classified as very high categories, students who have interpretation of critical thinking $75 \% \times<90 \%$ there are 3 people belonging to the high category, students who are in the interpretation of $55 \% \mathrm{x}<75 \%$ there are 4 people belonging to the medium category, students who are in the interpretation $40 \% \mathrm{x}<55 \%$ there are 10 people belonging to the 
low category, and students who are in the interpretation $0 \% \mathrm{x}<40 \%$ there are 16 people who are classified as very low category.

The critical thinking skills of students is influenced by their lack of training in working on questions that have high-level thinking categories in the cognitive domains C4 to C6, besides that the factors that affect students' critical thinking are internal and external (Tumanggor, 2020). Internal factors of critical thinking include learning styles of students, experience, and characteristics possessed by students, while external factors that affect critical thinking skills are learning strategies and learning methods, as well as teacher teaching styles used in the learning process (Suciono, 2021).

\section{CONCLUSION}

From the data obtained the research, the research conclusion such as.

1) The validation of the technical study test instrument resulted in a value of 4.62 which was valid and the validation of the constructional study test instrument resulted in a score of 4.52 which was categorized as valid.

2) There are 5 students who get scores above the KKM, while those who get below the KKM are 30 students at SMA Negeri 1 Tanggul.

3) There are 16 students who have critical thinking skills very low category, 10 students have low category, 4 students have medium category, 3 students have high category, and 2 students in the critical thinking skills in the very high category

\section{REFERENCES}

Ardiawan, I. G. (2020). Kupas Tuntas Penelititan Tindakan Kelas (Teori, Praktik, dan Publikasinya). Bali: Nilacakra.

Baidlowi, Hisyam, Sunarmi, \& Sulisetijono. (2019). Pengembangan Instrumen Soal Essay Tipe Higher Order Thinking Skills (HOTS) Materi Struktur Jaringan dan Fungsi Organ pada Tumbuhan Kelas XI SMAN 1 Tumpang. Jurnal Pendidikan Biologi, 10(2), 57-65.

Cholik, C. (2017). Pemanfaatan Teknologi Informasi dan Komunikasi untuk Meningkatkan Pendidikan di Indonesia.Syntax Literate. Jurnal Ilmiah Indonesia, 2(6), 21-29.

Fanani, M. (2018). Strategi Pengembangan Soal Higher Order Thinking Skill (HOTS) dalam Kurikulum 2013. Journal of Islamic Religious Education, 2(1), 57-76.

Fazar, I. (2019). Penilaian Berbasis Perangkat Lunak Menuju Paperless Assessment. Yogyakarta: Deepublish.

Hobri. (2010). Metodologi Penelitian Pengembangan. Jember: Pena Salsabila.

Istiyono, E. (2018). IT-Based HOTS Assessment on Physics Learning as The 21st Century Demand at Senior High School: Expectation and Reality. International Conference on Science and Applied Science (ICSAC), 4(2), 1-6.

Karim, N. (2015). Kemampuan Berpikir Kritis Siswa dalam Pembelajaran Matematika dengan Menggunakan Model Jucama di Sekolah Menengah Pertama. Jurnal Pendidikan Matematika, 3(1), 92-104. 
Mauludiyah, H. (2020). No Name Learning. Jakarta: PT Elex Media Komputindo.

Plomp, \& Nieveen. (2012). Formative Evaluation in Educational Design Research dalam Tjeer Plom and Nieke Nieveen (Ed): An Introduction to Educational Design Research. Netherlands: Organisatie International Publications.

Riskiyah, Siskatur, Jannah, \& Aini. (2018). Analisis Kemampuan Berpikir Kritis Siswa SMA Berkemampuan Matematika Tinggi dalam Menyelesaikan Masalah Fungsi. Jurnal Tadris Matematika, 1(2), 111-122.

Rochmad. (2012). Desain Model Pengembangan Perangkat Pembelajaran. Jurnal Kreano, 3(1), 59-72.

Sinesis, dkk. (2019). Pengembangan Instrumen Tes Termodinamika untuk Mengukur Kemampuan Pemecahan Masalah (PsACAr) pada Mahasiswa Calon Guru Fisika. Jurnal Inovasi Dan Pemeblajaran Fisika, 6(2), 122-129.

Suciono, W. (2021). Berpikir Kritis: Tinjauan Melalui Kemandirian Belajar, Kemampuan Akademik dan Efikasi Diri. Indramayu: Adab.

Tumanggor, M. (2020). Berpikir Kritis: Cara Jitu Menghadapi Tantangan Pembelajaran Abad 21. Ponorogo: Gracias. 